UDC 821.162.1-31.09 Żeromski S.

https://doi.org/10.18485/ms_zmss.2020.97.9

\title{
Adriana Pogoda-Kołodziejak
}

Uniwersytet Przyrodniczo-Humanistyczny w Siedlcach

\section{Adriana Pogoda-Kołodziejak}

Siedlce University of Natural Sciences and Humanities

\author{
„ENERGIA NARODOWA” WIATRU OD MORZA \\ STEFANA ŻEROMSKIEGO. RECEPCJA UTWORU \\ W 1922 ROKU
}

\author{
„NATIONAL ENERGY” IN WIND FROM THE SEE \\ BY STEFAN ŻEROMSKI. THE RECEPTION \\ OF THE WORK IN 1922
}

Stefan Żeromski był wielkim autorytetem dla polskiej inteligencji. W jego książkach, które powstawały w latach zaborów, widać ogromną wiarę w to, że ma ona do wypełnienia zadanie moralnej odnowy narodu poprzez kształtowanie postaw patriotycznych. W Wietrze od morza pisarz tchnie „,narodowa energie”, która zaraz po odzyskaniu niepodległości jest tak potrzebna i to nie elitom politycznym ale przede wszystkim zwykłemu, przeciętnemu obywatelowi, który bez względu na swoją indywidualną historię musi stawić czoła nowemu wyzwaniu, jakim jest odrodzona Polska. Żeromski nie bał się wielkich słów, były one w tym czasie konieczne i potrzebne, aby budować, kształtować i rozwijać „energię narodowa” wśród Polaków. Nie ulega wątpliwości, że Wiatr od morza w pełni oddaje moc narodu polskiego. Polska.

Stowa kluczowe: Wiatr od morza, Stefan Żeromski, “energia narodowa', odrodzona

Stefan Żeromski was a great authority for the polish intelligence. In his books, were written during the Partitions, we can see a powerful believe that it has the task to morally renew the nation by forming a patriotic attitude. In Wind from the sea the writer will infuse the "national energy" that shortly after regaining the independence is so much needed, not by the political elites, but chiefly by a regular, average citizen who, regardless of their individual history, has to face a new challenge that is the reborn Poland. Żeromski did not fear big words, at that time they were necessary and needed to build, form and develop the "national energy" among Polish people. There is no doubt that Wind from the sea fully expresses the might of the polish nation. Poland.

Key words: Wind from the sea, Stefan Żeromski, "national energy", the reborn

1 Określenie pochodzi z recenzji Wiatru od morza Stefana Żeromskiego, napisanej przez Wincentego Rzymowskiego (Rzymowski 1922). 
Wiatr od morza stanowi wraz z utworem Międzymorze i poematem Wisła trylogię nadmorską Stefana Żeromskiego. Bernard Chrzanowski² uważa, iż tekst zaczął powstawać w 1920 roku, kiedy Żeromski poprosił o dostarczenie mu literatury o Kaszubach oraz utworów pisanych w gwarze kaszubskiej3

Dla mnie - pisał Wincenty Rzymowski — pierwszego z brzegu czytelnika, dzieło to jest jednym z najżywotniejszych aktów energii narodowej, dochodzącej do poczucia i ujęcia swej treści. Jest świadectwem, jakie składa sama sobie moc niespożyta narodu. Jest — rzekłbym — pierwszą istotą nową, pierwszą duszą odrodzoną, pierwszym gościem, godnym wstępu do chramu wyjarzmionej ojczyzny (Rzymowski 1922).

Utwór wzbudził ogromne emocje wśród krytyków literatury, którzy $\mathrm{z}$ wielkim zaangażowaniem komentowali w licznych recenzjach Wiatr od mo$r z a$. Pojawiały się w nich różnorakie określenia pracy Żeromskiego, takie jak na przykład: „podręcznik polskiej prozy”, „,rapsod plemienny”, „,bajeczna księga”, „,czyn obywatelski”, „dzieło wielkiej sztuki” czy „triumf polskiego słowa". Krytycy zachwycali się konstrukcją, kształtem artystycznym, bogactwem języka, plastycznością opisów, dokładnością naukową (zob. Eile 1965: 194-196). Cóż takiego było w tym utworze, że krytyce używali tak wzniosłych słów? Jest to temat bardzo rozległy, podejmę jednak w tym artykule próbę ukazania „energii narodowej”, „płynącej” z utworu Żeromskiego w świetle wybranych recenzji ${ }^{4}$.

2 Bernard Chrzanowski był prawnikiem i publicystą żyjącym w latach 1861-1944. Był działaczem niepodległościowym w Poznańskiem oraz propagatorem polskości Pomorza. Był twórcą między innymi Na kaszubskim brzegu, Nad polskim morzem, Z wybrzeża i o wybrzė̇u (zob. Krzyżanowski 1984, 1: 144).

3 Były to przede wszystkim książki i słowniki żyjącego w latach 1852-1902 kaszubskiego poety, folklorysty, dziennikarza i współtwórcy kaszubskiego języka literackiego Hieronima Derdowskiego (zob. Krzyżanowski 1984, 1: 185), jak też Aleksandra Majakowskiego, żyjącego w latach 1876-1938 działacza kaszubskiego, twórcy i ideologa ruchu młodokaszubskiego, wieloletniego redaktora i współpracownika czasopisma Gryf, Gazeta Gdańska, Dziennik Gdański, twórcy powieści w gwarze kaszubskiej Żëce i przigodë Remusa i Zvjercadto kaszubskji, (zob. Krzyżanowski 1984, 1: 627) oraz Floriana Ceynowy, kaszubskiego folklorysty, językoznawcy, pisarza i działacza politycznego, żyjącego w latach 1817-1881, który swoje badania na temat Kaszub zawarł w publikacjach źródłowych: Obrazcy Kaszebskago narieczija, Sto frantóvek z połudnjovej częścij Pomorza Kaszubskiego i Sbjór pjenj svajtovih, zawierając w nich liczne pieśni, podania, bajki, przysłowia, opisy obyczajów i miejscowe nazewnictwo (zob. Krzyżanowski 1984, 1: 131). Z wydawanego w latach 1908-1913 w języku niemieckim organu prasowego Kaszubskiego Towarzystwa Ludoznawczego „Mitteilungen für kaschubische Volkskunde" (zob. Krzyżanowski 1984, 1: 336) oraz roczników literacko-etnograficznego miesięcznika krzewiącego ruch młodokaszubski pt. Gryf (zob. Szulc (red.) 1995, 6: 215) przyswoił Żeromski literaturze polskiej cały szereg wyrazów i nazw kaszubskich. Korzystał również z książki Bernarda Chrzanowskiego Na kaszubskim brzegu oraz ze słowników morskich (zob. Eile, Kasztelowicz 1976: 493).

4 Artykuł opiera się na recenzjach z 1922 roku, które ukazały się zaraz po wydaniu Wiatru od morza. W późniejszych latach ukazywały się również recenzje nawiązujące do tego utworu, jak np. Lam 1923, Zagórski 193. 
Stefan Żeromski był wielkim autorytetem dla polskiej inteligencji. W jego książkach, które powstawały w latach zaborów, widać ogromną wiarę w to, że inteligencja ma do wypełnienia zadanie moralnej odnowy narodu poprzez kształtowanie postaw patriotycznych. Miłość do ojczyzny, społecznikostwo, poświęcenie własnego życia dla dobra ogółu to postawy propagowane w jego utworach, takich jak m.in. „Siłaczka”, „Ludzie bezdomni”, „Popioły” czy „Wierna rzeka”. Wzbudzały one zachwyt wśród polskich czytelników, walczących o niepodległość państwa. Był on ,nie tylko pisarzem, lecz przede wszystkim wielkim patronem tego pokolenia inteligencji, które budowało Niepodległą, [...] zaszczepił wiarę w ideały wolności, poszanowania każdego człowieka bez względu na jego status społeczny i wpoił świadomość piękna bezinteresownej pracy dla kraju" (Kowalczykowa 2013: 7). Sam Żeromski w swoim odczycie wygłoszonym w Zakopanem w roku 1915 określił cel literatury, którym obok wartości estetycznej na pierwszy plan wysuwa się poszukiwanie drogi do szczęścia dla kraju Polaków. W 1918 roku, już w nowej rzeczywistości, Żeromski propaguje postawę bezinteresownego poświęcenia się dla ojczyzny oraz dokonuje reinterpretacji pojęcia patriotyzmu, co widoczne jest w napisanej w 1917 roku pt. „Wiśle” (Kowalczykowa 2013: 12-13).

W 1920 roku pisarz zamieszkał w wynajętym domu w Orłowie, do którego przyjeżdżał co roku i zbierał materiały do swojego literackiego zamierzenia. Dążył do dokładnego zapoznania się z życiem ludzi na wybrzeżu oraz działał w Towarzystwie Przyjaciół Pomorza, którego był współtwórcą. W tym samym roku, podczas plebiscytu na Mazurach, przebywał także „w Kwidzynie, Iławie, Suszu, Sztumskiej Wsi i Malborku. Poznał tam lepiej skutki długowiecznej germanizacji, zaglądał do zagród i chat, niosąc słowa pociechy i pokrzepienia, bywał na wiecach i uroczystościach narodowych, rozmawiał z członkami komisji koalicyjnej, wglądał głęboko w akcję plebiscytową, interesował się każdym szczegółem" (Kucharski 1989: 12). Tak samo interesował się kwestią dostępu do morza i kulturą Kaszubską. Latem 1921 roku, przebywając w Gdyni opublikował w dodatku do Dziennika Gdańskiego nr z 11 września fragment Wiatru od morza pt. „Smętek w wiośnianej dolinie” (zob. Paszek 2001: 166). Kolejnym wydanym fragmentem utworu był Łgorz przesłany przez Żeromskiego 7 lutego 1922 do nowego miesięcznika poznańskiego Strażnica Zachodnia. 21 lutego tego samego roku zakończył całość swojego cyklu5, który ukazał się drukiem pod koniec marca lub na początku kwietnia w Wydawnictwie J. Mortkowicza, Towarzystwo Wydawnicze w Warszawie. Drugie wydanie ukazało się w tym samym roku (zob. Eile/Kasztelowicz 1976: 512). Już na początku maja 1922 roku pojawiły się pierwsze, bardzo entuzjastyczne recenzje Wiatru od morza. Książka rozeszła się w trzy tygodnie, w liczbie 10 tysięcy egzemplarzy i tłumaczona była od razu na język francuski i rosyj-

5 Istnieje teoria, według której Żeromski napisał fragmenty Wiatru od morza w latarni na Rozewiu. Do dziś to założenie nie jest udokumentowane, faktem jest jedynie to, że pisarz lubił tam przebywać wraz ze swoją rodziną i znajomymi, ale nigdy tam nie mieszkał (zob. Eile/Kasztelowicz 1976: 506). 
ski. Również firma Wood et Co z Nowego Jorku poprosiła o autoryzację przekładu (Eile/Kasztelowicz 1976: 514).

Tytuły nadawane przez Żeromskiego utworom rzadko mają charakter informacyjny, lecz są zazwyczaj środkiem interpretacji emotywno-oceniającej. I tak, tytuł Wiatr od morza to symboliczne ujęcie zjawiska, które zaczerpnięte zostało przez pisarza z rzeczywistości (zob. Markiewicz 1977: 23). Znaczenie tytułu jest nie tylko trafne, symboliczne, realne, ale i tchnące optymizmem. Poprzez obrazy historyczne rozpoczynające się apostolską wyprawą i męczeństwem św. Wojciecha, a zakończone budową polskiego portu w Gdyni, zostało ukazane wiekowe niebezpieczeństwo grożące Polsce ze strony Niemiec. Pierwsze pięć opowieści Wiatru od morza (,Napad Jutów”, „Smętek”, „Drang nach Osten”, „Smierć świętego Wojciecha”, „Los Zbigniewa”) to cykl z najdawniejszych dziejów Pomorza, ukazujący germańskie parcie na wschód, okrutne zbrodnie ludów północy w chrześcijańskiej Europie. W czterech opowieściach poświęconych Krzyżakom („Pokłon Hermana Balka”, „Rzeź w Gdańsku”, „Zagłada Dworu”, „Bitwa pod Świecinem”) najważniejsze są fakty historyczne, a przede wszystkim polityczna działalność Zakonu. Kolejne pięć utworów (,Jan z Kolna”, „Kopernik”, „Fryderyk II na Pomorzu”, „Jan Dąbrowski pod Gdańskiem”, „Czarownica”) prezentują wydarzenia ze znacznymi lukami czasowymi. Życie odradza się po wypędzeniu Krzyżaków, aby już za moment dostać się w jarzmo Prus po pierwszym rozbiorze. Ostatni cykl to cztery opowiadania („Otto von Arffberg”, „Czekaj”, ,Przy nowych fundamentach”, „Odjazd Smętka”) o czasach współczesnych Żeromskiemu. Pisarz podkreśla, że przemoc narodu nad narodem wynika z pruskiej zaborczości i bezwzględnego wyzysku. Ci, którzy budują port gdyński pochodzą z ziem byłych zaborów Polski. Jest to symbol zjednoczenia narodu wokół wspólnej sprawy, jaką jest odbudowa wyzwolonego państwa.

Po przeczytaniu utworu czytelnik ma przeświadczenie, że między Polakami a Niemcami nastanie pokój ${ }^{6}$, gdyż pomimo wielu negatywnych faktów historycznych, pojawiających się w książce pisarz nie głosił w niej nienawiści do Niemców, lecz, jak twierdzili krytycy, był bardzo obiektywny w swoich osądach, a książka ta, którą traktowano jak traktat polityczny, była wręcz próbą pojednania (zob. Eile 1965: 226). W rzeczywistości nie jest to żaden traktat polityczny, ani agitacja, ani rachunek krzywd polskich czy niemieckich. Jest to przedstawienie zdarzeń dziejowych w taki sposób, by czytelnik zrozumiał, iż historia kieruje się własną logiką, ma swoje prawa, które determinują zarówno jednostki, jak i narody. W Wietrze od morza w opozycji względem siebie stoją dwa czynniki: instynkt walki i zniszczenia oraz pokój i miłość. Bohaterowie są wcieleniem tych właśnie sił. Ostatnia opowieść cyklu niesie otuchę, wojna skończona a Polska odzyskuje nadmorską ojcowiznę, nienawiść zostaje zastąpiona ideą przebaczenia i pojednania (zob. Hutnikiewicz 2000: 222-223).

6 zob. Borowy, bez miejsca i roku wydania: 129. 
Wiatr od morza ,w oczach krytyków” w 1922 roku

Budowa portu w Gdyni, dostęp Polski do morza dawało poczucie przynależności do innych państw oraz poczucie tak wytęsknionej i wyczekiwanej przez naród polski wolności. Wszyscy pragnęli tej wolności, ale nie wszystkim odpowiadało pozytywne nastawienie Żeromskiego do pojednania z zaborca niemieckim i chęć zamknięcia pewnego etapu dziejowego. „Energia narodowa” Wiatru od morza to przede wszystkim próba zjednoczenia polskiego społeczeństwa tak ogromnie zróżnicowanego w wyniku życia kilku pokoleń pod rządami zaborców.

Temu miało służyć sięgnięcia pisarza do źródeł: do gwary i do legend, by wszyscy czytelnicy mogli zrozumieć jedność narodu polskiego. Na tym właśnie polegał sukces Wiatru od morza i z tego też powodu nie dziwi fakt pojawienia się wielu skrajnych recenzji, gdyż były one uzależnione zarówno od przekonań politycznych krytyka, jak też jego przeżyć i oczekiwań względem nowo tworzącej się rzeczywistości politycznej. Jednak recepcja utworu była przede wszystkim pozytywna, co widać już było po tytułach niektórych recenzji, jak np. „,Wiatr od morza” S. Żeromskiego. Arcydzieło prozy polskiej autorstwa Eustachy Czekalskiego, opublikowanej na łamach dodatku „Powieść i nowela" do 16 numeru czasopisma Świat w 1922 roku. Zwraca on uwagę na fakt, że pisarz potrafi suchym faktom i pojęciom nadać wartość artystyczną (zob. Czekalski 1922).

W czterech numerach „Rzeczpospolitej” z roku 1922 krytyk literacki i teatralny Adam Grzymała-Siedlecki, który nie był przychylny Żeromskiemu, zmienia swoje nastawienie względem pisarza i określa Wiatr od morza mianem „rapsodu plemiennego [...] kilkunastowiekowego istnienia narodu” (Grzymała-Siedlecki 1922a: 4-5). W drugiej części swojej recenzji opisuje kwestię morską jako temat przewodni dzieła (Grzymała-Siedlecki 1922b: 4-5), zaś w trzeciej zwraca uwagę na to, że utwór ten mówi o konieczności czuwania nad istnieniem narodu poprzez pielęgnowanie historii, gdyż jest ona punktem wyjścia dla przyszłości kraju (Grzymała-Siedlecki 1922c: 4-5). Dla niego walka i energia w Wietrze od morza stanowią siłę twórczą państwa, którą utożsamia z postacią Smętka7. Recenzent przedstawia walkę z germanizmem w duchu Romana Dmowskiego. Wyczuwa się tutaj silny kompromis chrześcijańsko-endecki, który prowadzi Grzymałę-Siedleckiego do bardzo indywi-

7 Prawdopodobnie w kulturze przedchrześcijańskiej było to bóstwo smutku, które potem stało się złym duchem i „najwyższym z diabłów”. Był on protektorem nierządu i często przybierał postać dziewczyny, stał na granicy dobra i zła (zob. Podgórscy 2005: 416). Po raz pierwszy w literaturze postać ta - kaszubski diabeł - wystapiła w poemacie Jarosza Derdowskiego O panu Czorlińscim co do Pucka po serce jachoł, ale rozgłos zyskał dzięki Żeromskiemu. Więcej na ten temat zob. w: Kucharski 1976: 45-64. Ta kaszubska istota demoniczna jest tutaj uosobieniem wszelkiego zła, symbolem przemocy i zbrodni, a jednocześnie walki dobra ze złem. Dzięki niej pisarz ukazuje różne odmiany zła, które gnębił ludzkość. $\mathrm{W}$ ostatnich czterech powieściach rozgrywających się w XX wieku staje się on uosobieniem ucisku narodowego, który zostaje przezwyciężony. 
dualnej interpretacji dzieła Żeromskiego, o czym świadczy chociażby fakt, że chętnie zmieniłby zakończenie utworu tak, by Smętek nie odjeżdżał z kraju do Anglii lecz, by dzięki sile narodowej został „nawrócony” i pozostał na stałe w Polsce (Grzymała-Siedlecki 1922d: 4-5). Czytając tę rozbudowaną i szczegółową recenzję widać wyraźnie, jak książka wpłynęła na odbiorców różnych opcji politycznych i jak bardzo rozgrzewała poczucie jedności narodu, pomimo różnic ideowych wśród Polaków.

Adolf Nowaczyński w swojej ocenie napisał: „Wielki pisarz, myśliciel i wychowawca dzisiejszego pokolenia, właściwy siewca ziarna idei niepodległościowej, [...] w nowym swoim utworze daje retrospektywny, epopejowy, groźny obraz pangermańskiego »Drang nach Osten« i drapieżną, bezlitosną, nieludzką psychikę bynajmniej jeszcze niezdławionego krzyżactwa"8. Ta recenzja bardzo silnie wskazuje na negatywne skojarzenia z zakonem krzyżackim, który w czterech częściach Wiatru od morza jest uosobieniem zła i zniewolenia. „Historie krzyżackie” są nawiązaniem do sytuacji rozbiorowej Polski. Nowaczyński podkreśla w swojej recenzji pracowitość, jak i miłość do Ojczyzny pisarza, który poprzez publikację zwraca uwagę na najbardziej po macoszemu traktowanych kaszubskich Pomorzan.

Wiatr od morza to entuzjastyczny hymn na chwałę życia, „wiara, zaufanie w siły człowieka, potwierdzenie wartości życia i znaczenia twórczego czynu" (Kisielewski 1922a). Ten zachwyt nad dziełem Żeromskiego odnajdujemy w recenzji Zygmunta Kisielewskiego, który bardzo mocno zwraca uwage na polskiego ducha utworu. Odnajdujemy go przede wszystkim w literackim unieśmiertelnieniu morza, czego dokonał pisarz jako pierwszy. Chwała Żeromskiego jest tym większa, że nikt z młodego pokolenia tamtych czasów nie podjął się tego tematu, a on, który kształtował już duszę polska przedwojennego pokolenia okazał się nadal pozostawać młody duchem. Książka jest według recenzenta „wezwaniem, które umysły pokolenia wchodzącego na otwartą arenę życia odrodzonego państwa zwróci czołem w stronę najważniejszego zagadnienia naszej przyszłości, którego treścią realną a zarazem symbolem jest Morze czyli wielkość" (Kisielewski 1922b). Można ją osiągnąć jedynie zmagając się z żywiołami i poprzez związanie się jednostki ze sprawami dziejowymi.

Na temat wielkości utworu Żeromskiego rozpisywał się na łamach „Skamandra” Emil Breiter. Określił go „triumfem polskiego słowa”, który wyznacza drogi dla przyszłych pokoleń. Recenzent nazywa ten utwór zwycięskim sztandarem Ormuzda, hasłem rozesłanym do wszystkich polskich dusz, że naród może „śpiewać hosanna” po zwyciężeniu zła i „zakasać rękawy do znojnej, twórczej, ale już radosnej i boskiej sprawy”. Wyobraźnia pisarza została „rozdymana" wiatrem od morza, który tchnie siłę samowiedzy, konieczność wspólnego działania i podjęcia zbiorowego czynu, dzięki czemu książka ta „nabiera

8 Zob. Nowaczyński 1922. Cyt. za: Eile/Kasztelowicz 1976: 514. 
charakteru nowej ewangelii polskiej, jakichś na nowo napisanych kart polskiego pielgrzymstwa", dając siłę narodowi do pracy nad swoją przyszłością (zob. Breiter 1922: 252-258).

Nie brakowało w opiniach zachęty do czytania Wiatru od morza, który miał wnikać w tysiące serc i naprężać miliony ramion. Co miał na myśli Teodor Tyc pisząc takie słowa? Uwzględniając, że według niego „[w]ielcy pisarze są mocarzami w życiu narodu" (zob. Tyc 1922: 88-93) można wywnioskować, że chodzi mu o budowę jednolitej myśli narodowej i krzewienie patriotyzmu, by w momencie zagrożenia zewnętrznego jako naród razem naprężyć ramiona do walki.

Inny krytyk literacki, Karol Lielienfeld-Krzewski, w czasopiśmie społeczno-kulturalnym Droga zwrócił uwagę na ogromną wiedzę Żeromskiego i znakomite przygotowanie historyczno-naukowe do napisania Wiatru od morza (Lielienfeld-Krzewski 1922c: 26-27). Odwołując się w pierwszej części swojej recenzji do odczytu Żeromskiego w Zakopanem na temat Literatura

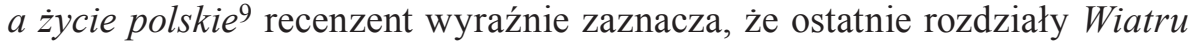
od morza są opisowo publicystyczne i powinny ją przeczytać wszystkie referaty narodowościowe, by zapoznać się z przedstawioną przez pisarza agitacją za i przeciw Polsce, prowadzoną z kaszubskiego brzegu. Fragmenty utworu powinny być czytane wycieczkom szkolnym zwiedzającym port gdański, jak też kursom szkoły podoficerskiej, by zrozumieli ,jakie to dla narodu znaczenie olbrzymie posiada port wojenny". Mamy tu do czynienia z pewną formą dydaktyzacji, która wypływa z mocy i „,nadziei narodu” (zob. Lielienfeld -Krzewski 1922b: 29-31).

Mieczysław Rettinger w Kurierze Lwowskim twierdził, że dzieło to przewyższa wszystkie w ostatnim czasie powstałe powieści, wywołując tak długo oczekiwane silne wrażenie dzięki wyjściu na przeciw czytelnikowi, który od lat czekał na literaturę owianą ,urokiem metafizycznej koncepcji, bujającej w obłokach chwały narodowej" (Rettinger 1922).

Natomiast Piotr Dunin-Borkowski w swojej analizie Wiatru od morza, opublikowanej na łamach Stowa Polskiego stwierdza, że opis Pomorza, kraju przechodzącego przez wieki z rąk do rąk znakomicie nadaje się do ukazania idei narodowej, ukazywanej w literaturze polskiej, jednakże zarzuca pisarzowi liberalizm i uwalnianie Niemców od winy za wieloletnie zniewolenie narodu polskiego. Pomimo to uważa, że dzieło Żeromskiego niesie pociechę i radość tym, „dla których sprawy ducha ludzkiego są ważniejsze ponad wszystkie namiętności materialne" (zob. Dunin-Borkowski 1922a, 1922b).

$\mathrm{Na}$ bogactwo języka i najoryginalniejsze dzieło dotychczasowej poetyckiej prozy, celowość konstrukcji dzięki której powstał nowy kształt artystyczny zrodzony z ,zadumy poety nad zagadnieniami życia narodowego” zwraca

9 Odczyt ten miał miejsce w sierpniu 1915 roku, pierwszy raz został wydrukowany w Kurierze Lwowskim w 1926 roku i wywołał wielką polemikę na temat zadania literatury i jej funkcji w społeczeństwie (zob. Lilienfeld-Krzewski 1922a: 17). 
uwagę w swojej trzyczęściowej recenzji Jan Lorentowicz na łamach Tygodnia Polskiego (zob. Lorentowicz 1922b, 1922c). Zaznacza w niej również, że w brzasku niepodległości literatura polska otrzymała nowe zadanie, którego wielu pisarzy nie podjęło. Jednak pisarz starszego pokolenia, Stefan Żeromski, „który przed wojną we wszystkich swych pismach odtwarzał ukryte, podziemne nurty serc polskich, zjawia się oto z nową księgą, w której wielki jego talent dochodzi do najwyższego napięcia" (zob. Lorentowicz 1922a).

Jan Nepomucen Miller mówi w czasopiśmie Ponowa o ratowaniu przez Żeromskiego honoru starszego pokolenia pisarzy polskich, zaznaczając, że dzieło to „powitała cała krytyka polska od prawego do lewego skrzydła jednym głosem uznania i zachwytu" (Miller 1922: 444-445). Jako chyba jedyny recenzent zauważ pojawiający się w dziele motyw zniechęcanie do walki i ogromne pragnienie spokoju.

Według Leona Piwińskiego Wiatr od morza osiąga mistrzostwo w piękności stylu tworząc podręcznik polskiej prozy, o czym pisze w swojej ocenie na łamach Przeglądu Warszawskiego (Piwoński 1922).

Cezary Jelenta na samym początku swojej recenzji w Gazecie Administracji i Policji Państwowej określa Wiatr od morza mianem dzieła ,wielkiego znaczenia literackiego i narodowego". Dzieło to jest propagandą historii i uświadomienia patriotycznego. Jelenta nawołuje tych, którzy zrozumieją propagandowy ton utworu do pouczania wszystkich ,o opatrznościowej sprawiedliwości, która przywróciła Pomorze Polsce, i o obowiązkach względem Kaszubów, których ducha narodowego i obywatelskiego trzeba odbudowywać z zamętu niszczącej roboty pruskiej" (Jellenta 1922).

W Kurierze Warszawskim recenzent Zdzisław Dębicki przyrównuje dzieło Żeromskiego do bursztynu który długo leżał na dnie morza, by po latach zabłysnąć w pełnej krasie twórczej woli pisarza. Dzięki tak wspaniałemu przedstawieniu historii książka ta jest w stanie wzbudzić zrozumienie Polaków dla sprawy kaszubskiej (Dębicki 1922).

Gazeta Lwowska i także wydawana we Lwowie Gazeta Poranna również umieściły na swoich łamach recenzje Wiatru od morza. W pierwszej z gazet Jadwiga Tomicka określiła ten utwór mianem dążenia naprzód by udoskonalić ludzkość (Tomicka 1922a, 1922b), zaś w drugiej Zenon Aleksandrowicz mówi o wnikaniu dzieła w głąb duszy i konieczności wysiłku ducha, by sprostać jego potędze (Aleksandrowicz 1922). Również w czasopiśmie kobiecym jakim był Bluszcz odnajdujemy „Rapsod o Smętku i Pomorzu”, recenzję Stefanii Podhorskiej-Okołów, dla której Żeromski wraz ze swoim utworem jawi się jako wieszcz dziejów Pomorza (zob. Eile 1965: 229).

Jak można zauważyć na podstawie powyższych przykładów te pozytywne recenzje dotyczyły różnych kwestii, jedni kładli nacisk na wydźwięk narodowy utworu, inni, będąc najwyraźniej bardziej zachowawczymi, zwracali uwagę na kwestie techniczne i językowe, ale i w nich czuć było zachwyt patriotyzmem pisarza, gdyż styl pisania, bogate słownictwo, historie oparte 
na opowieściach ludowych są również nośnikami „energii narodowej” Wiatru od morza.

Nie brakowało również słów krytyki pod adresem utworu. Stanisław Baczyński określił je mianem ,grzechu” wobec literatury i uważał, że jest to rozprawa literacko-historyczna, a nie powieść, w której kompozycję zastąpiła chronologia (zob. Eile 1965: 231). Również negatywny stosunek do dzieła Żeromskiego mieli przedstawiciele KPP ${ }^{10}$. Na łamach Kultury Robotniczej pod pseudonimem „Jan” pojawiła się niepochlebna recenzja dzieła Żeromskiego, której autorem był prawdopodobnie Jan Hempel ${ }^{11}$. Zarzucał on Żeromskiemu brak idei i myśli przewodniej uzasadniającej prawo Polski do Pomorza, które według niego powinny były być mocno zaznaczone i wyrażone w utworze. Twierdził również, że jest on tendencyjny, głosi nienawiść do Niemców, których w tym przypadku ucieleśnieniem są Krzyżacy i że brak mu głębszej myśli. Także Jan Parandowski w swojej recenzji dla Kuriera Poznańskiego pomimo pozytywnej oceny języka utworu oraz stwierdzenia, że Żeromski posiada dar „przenikania rzeczy, stosunków i duszy, który jest darem tylko największych artystów" (Parandowski 1922), nie szczędzi słów krytycznych na temat stylu i braku prawidłowej konstrukcji dzieła.

Zarzuca Żeromskiemu zastosowanie zbyt wielu szczegółów i przytłaczającej liczby drobiazgów. Oskarża on również pisarza o brak ewolucji jego duszy, która to cały czas jest w okresie niewoli, zaś radość utworu jest fałszywa, gdyż bije z niego „spleśniały osad smutku, żalu i zgryzoty” (Parandowski 1922). Recenzent zaznacza, że sięgnął do książki, gdyż była to ważna nowość, na temat której słyszał wiele zachwytów, jak też i słów niechęci. Niestety uważa on książkę Żeromskiego za pełną smutku, udręki, cierpienia i zawiści, zupełnie nie odnajduje na jej kartach krzepiącej pieśni mającej dać energię na odrodzenie narodu.

W Szwecji doszło do polemiki na temat dzieła Żeromskiego między doktorem Adolfem Stender-Petersenem, docentem Högskola w Göteborgu a profesorem Böökiem. Adolf Stender-Petersen, znawca polszczyzny, czytający dzieła Żeromskiego w oryginale, nazwał Wiatr od morza ,fanfarą zwiastującą początek nowego życia w historycznym rozwoju Polski, hasłem działania na przyszłość, a zarazem syntezą przeszłości - prawdziwym arcydziełem lirycznego natchnienia"12. Böök, 4 października 1924 roku, napisał do Svenska dagbladet bardzo ostrą i zjadliwą krytykę opartą na felietonach z prasy niemieckiej, w której dając upust swoim tendencjom germanofilskim, podkreślił występowanie w Wietrze od morza germanofobii, polskiego imperializmu oraz stwierdzając, iż utwór ten jest sztuką na usługach polityki13 ${ }^{13}$.

\footnotetext{
10 KPP - Komunistyczna Partia Polski.

11 Jan Hempel, działacz polityczny, krytyk literacki, publicysta i wydawca żyjący w latach 1877-1937, związany z polskimi partiami lewicowymi (zob. Krzyżanowski 1984: 343).

12 Stanisław Wędkiewicz, Żeromski w Szwecji (cyt. za: Eile/Kasztelowicz 1976: 519).

13 Stanisław Wędkiewicz, Żeromski w Szwecji (cyt. za: Eile/Kasztelowicz 1976: 537).
} 


\section{Podsumowanie}

W roku 1924 Żeromski otrzymał za najlepszą pracę literacką w latach 1922-1924, czyli za Wiatr od morza, Nagrodę im. Orzeszkowej (zob. Eile/ Kasztelowicz 1976: 553). Nie była to jedyna nagroda dla pisarza za ten utwór. W tym samym roku kandydatura Stefana Żeromskiego została wysunięta do Nagrody Nobla, do której pretendował również Władysław Reymont. Przekłady dzieł Żeromskiego szybciej niż Reymonta dotarły do czytelników za granicę dzięki tłumaczce Ellen Westen i referentowi literatur słowiańskich przy Komitecie Nobla doktorowi Alfredowi Jensenowi, który był zwolennikiem przyznania Nobla właśnie Żeromskiemu. Niestety, śmierć Jensena oraz brak przychylności, a wręcz niechęć członka Szwedzkiej Akademii profesora Booka, prezentującego proniemiecką orientację, krytykującego Wiatr od mo$r z a$, doprowadziły do odrzucenia kandydatury Żeromskiego do Nagrody Nobla (zob. Łoch 2008: 69). Nobel trafił do Władysława Stanisława Reymonta, a Żeromski musiał się zadowolić Państwową Nagrodą Literacką (Eile, Kasztelewicz 1976: 562). 26 stycznia 1925 roku została wręczona pisarzowi Nagroda Ministra Wyznań Religijnych i Oświecenia Publicznego. „Czuję się bardzo w tej chwili szczęśliwy — odpowiedział autor kierownikowi Ministerstwa że to dzieło, które mnie kosztowało tyle pracy i w którym chciałem znaleźć nową formę literacką, spotkało się z uznaniem Pana Ministra"14.

Jak można zauważyć z powyższych relacji twórczość Stefana Żeromskiego wywoływała ogromne emocje i nie można było przejść obok niej obojętnie. Pomimo słów krytycznych Wiatr od morza cieszył się w latach międzywojennych dużym uznaniem społecznym $i$,dla sprawy morskiej ${ }^{15} \mathrm{w}$ Polsce był tym, czym dla bytu narodowego Polaków były takie dzieła, jak Dziady i Pan Tadeusz Mickiewicza, jak Sienkiewicza Trylogia"16. Nie ulega wątpliwości, że Wiatr od morza ma „charakter państwowotwórczy”, a pisarz z pesymisty stał się człowiekiem entuzjastycznie nastawionym do niepodległej Polski (Eile 1965: 214-215). Żeromski wierzył w siłę literatury, w jej wpływ na świadomość czytelnika i w to, że jest ona w stanie wzbudzić w odbiorcy niepokój moralny, a przede wszystkim brak przyzwolenia na zło. W Wietrze od morza wyraźnie widać radość pisarza z odzyskania niepodległości oraz wielką nadzieję na świetlistą przyszłość narodu polskiego. W cyklu tym głównym bohaterem nie jest osoba, a polska ziemia oraz jej tragiczne losy, ziemia cudownie ocalona i powracająca na nowo do życia. Żeromski i w tym przypadku okazuje się być

14 Jan Zygmunt Jakubowski, Stefan Żeromski (cyt. za: Pękala 1982: 108).

15 Chodzi tu o przyłączenie Pomorza do Polski po odzyskaniu niepodległości.

16 Zob. Kucharski 1976: 5. Należy jednak pamiętać, że po mimo porównywania Żeromskiego z Sienkiewiczem i nazywania go jego następcą to pisarz „zakwestionował niemal wszystkie konwencje górujące w dojrzałej fazie realizmu krytycznego: przezroczystość stylu, neutralizację narratora, zniknięcie komentarza autorskiego, dramatyczną budowę noweli, koncentrację fabuły powieściowej, racjonalistyczną konsekwencję rozwoju psychologicznego bohaterów, przewagę konfliktów życia prywatnego na pierwszym planie tematyki powieściowej" (Markiewicz 1977: 16). 
wielkim pisarzem narodowym, który społeczeństwo obdarza ogromną energią patriotyczną wskazując mu drogi do polskości.

123 lata Polska nie istniała na mapach świata i przez ten czas mógł zostać zniszczony duch narodu. Nie udało się to jednak zaborcom, o czym świadczy właśnie dzieło Żeromskiego, które napawa wielkim optymizmem odrodzenia się narodu i myśli narodowej. Pisarz - strażnik wichru polskiego ducha, jak określa go Kisielewski, po wielkim wycieńczeniu „polskiego organizmu” tchnie nową „,narodową energię”, która zaraz po odzyskaniu niepodległości jest tak potrzebna i to nie elitom politycznym ale przede wszystkim zwykłemu, przeciętnemu obywatelowi, który bez względu na swoją indywidualną historię musi stawić czoła nowemu wyzwaniu, jakim jest odrodzona Polska. Być może są to słowa bardzo patetyczne, ale nie można inaczej pisać o tak wielkim wydarzeniu, gdyż byłaby to ignorancja i całkowite niezrozumienie sytuacji narodu polskiego. Żeromski nie bał się wielkich słów, były one w tym czasie konieczne i potrzebne, aby budować, kształtować i rozwijać „,energię narodową" wśród Polaków. Być może dzisiaj, w świecie pełnym idei kosmopolityzmu, sposób pisania Żeromskiego wydaje się bardzo naiwny, a patos jego dzieł potrafi zapewne niektórych śmieszyć. Bez względu jednak na politykę i rozgardiasz w otaczającym nas świecie warto spojrzeć i zachwycić się postawą pisarza a przede wszystkim jego słowem. Zacytowany w początkowej części artykułu Wincenty Rzymowski i jego określenie „energia narodowa”, które stało się myślą przewodnią niniejszego wywodu jest zarówno najlepszym wstępem jak i podsumowaniem przedstawionych tutaj recenzji Wiatru od mo$r z a$. Nie ulega wątpliwości, że utwór ten w pełni oddaje moc narodu polskiego i wskazuje drogi do bycia dobrym Polakiem, nie tylko w sytuacjach kryzysowych i zagrożeniach, ale przede wszystkim w czasie pokoju i budowania państwa polskiego, co nie jest cyklem skończonym, ale trwa cały czas.

\section{BIBLIOGRAFIA}

Aleksandrowicz Zenon. „'Wiatr od morza' S. Żeromskiego”. Gazeta Poranna 6430 (1922). https://jbc.bj.uj.edu.pl/dlibra/publication/187084/edition/176318/content?ref=desc, data dostępu: 25.05.2018.

Borowy Wacław. O Żeromskim. Rozprawy i szkice, bez miejsca i roku wydania.

Breiter Emil. „St. Żeromski: Wiatr od morza”. Skamander III/ 3-XIX (1922): 252-258. https:// academica.edu.pl/reading/readSingle?page=60\&uid=56329036, data dostępu: 21.06.2018

Czekalski Eustachy. „Wiatr od morza S. Żeromskiego. Arcydzieło prozy polskiej”. „Powieść i nowela" dodatek do ,Świat. Pismo tygodniowe ilustrowane 16 (1922). https://academica.edu.pl/reading/readMeta?cid=12244772\&uid=10532054, data dostępu: 22.06.2018.

Dębicki Zdzisław. „Wiatr od morza”. Kurjer Warszawski 98 (1922). https://academica.edu.pl/ reading/readSingle?page=7\&uid=19033558, data dostępu: 24.06 .2018 .

Dunin-Borkowski Piotr. „'Wiatr od morza' S. Żeromskiego”. „Słowo Polskie” 264 (1922a). https://jbc.bj.uj.edu.pl/dlibra/publication/211429/edition/200117/content?ref=desc, data dostępu: 21.06.2018;

Dunin-Borkowski Piotr. ,'Wiatr od morza' S. Żeromskiego”. Słowo Polskie 265 (1922b). https:// jbc.bj.uj.edu.pl/dlibra/publication/211430/edition/200118/content?ref=desc, data dostępu: 21.06.2018. 
Eile Stanisław. Legenda Żeromskiego. Recepcja twórczości pisarza w latach 1892-1926. Kraków 1965.

Eile Stanisław, Kasztelowicz Stanisław. Stefan Żeromski. Kalendarz życia i twórczości. Kraków 1976.

Grzymała-Siedlecki Adam. „Najnowsze dzieło Żeromskiego. O czem czytamy w 'Wietrze od morza"', Rzeczpospolita 96 (1922a): 4-5. https://academica.edu.pl/reading/readSingle?page=4\&uid=19640157, data dostępu: 21.06 .2018 .

Grzymała-Siedlecki Adam. „Najnowsze dzieło Żeromskiego. Idea morskości”. Rzeczpospolita 00 (1922b): 4-5. https://academica.edu.pl/reading/readSingle?page=4\&uid=19649051, data dostępu: 21.06.2018.

Grzymała-Siedlecki Adam. „Najnowsze dzieło Żeromskiego. Jestestwo Pomorza”. Rzeczpospolita 103 (1922c): 4-5. https://academica.edu.pl/reading/readSingle?page=4\&uid= 19640167, data dostępu: 21.06.2018.

Grzymała-Siedlecki Adam. „Najnowsze dzieło Żeromskiego. Filozofja walki”. Rzeczpospolita 106 (1922d) : 4-5. https://academica.edu.pl/reading/readSingle?page=4\&uid=19640171, data dostępu: 21.06 .2018

Hutnikiewicz Artur. Żeromski. Warszawa 2000.

Jelenta Cezary. „Wiatr od morza”. Gazeta Administracji i Policji Państwowej 35 (1922). https:// academica.edu.pl/reading/readSingle?page=13\&uid=47075111, data dostepu: 24.06.2018.

Kisielewski Zygmunt. „Wiatr od morza”. Robotnik 101 (1922a). https://academica.edu.pl/ reading/readSingle?page $=2 \&$ uid $=70288677$, data dostępu: 22.06 .2018 .

Kisielewski Zygmunt. „Wiatr od morza”. Robotnik 102 (1922b). https://academica.edu.pl/ reading/readSingle?page $=2 \& u i d=70288678$, data dostępu: 22.06 .2018 .

Kowalczykowa Alina. Stefan Żeromski w Niepodległej. Warszawa 2013.

Krzyżanowski Julian. Literatura Polska. Przewodnik encyklopedyczny. T. 1. Warszawa 1984.

Kucharski Jan. „Ideowe i kompozycyjne funkcje Smętka w "Wietrze od morza”. Pamiętnik literacki. Czasopismo poświęcone historii i krytyce literatury polskiej LXVII/1 (1976): $45-64$.

Kucharski Jan. Wiatr od morza Stefana Żeromskiego. Zarys monograficzny. Gdańsk 1989.

Lilienfeld-Krzewski Karol. „St. Żeromski: 'Wiatr od morza’”. Droga: dwutygodnik poświęcony sprawie życia polskiego 9 (1922a): 17-23. http://cyfrowa.chbp.chelm.pl/dlibra/ doccontent?id=5927\&dirids=1, data dostępu: 21.06.2018.

Lilienfeld-Krzewski Karol. „St. Żeromski: 'Wiatr od morza’”. Droga: dwutygodnik poświęcony sprawie życia polskiego 10 (1922b): 29-31. http://cyfrowa.chbp.chelm.pl/dlibra/ doccontent?id=5928\&dirids=1, data dostępu: 21.06 .2018 .

Lilienfeld-Krzewski Karol. „St. Żeromski: 'Wiatr od morza”. Droga: dwutygodnik poświęcony sprawie życia polskiego 11 (1922c): 26-27. http://cyfrowa.chbp.chelm.pl/dlibra/ doccontent?id=5929\&dirids $=1$, data dostępu: 21.06 .2018 .

Lorentowicz Jan. „Rapsodia Pomorza”. Tydzień Polski III/24 (1922a): 10-11. https://academica.edu.pl/reading/readSingle?page=10\&uid=56633843, data dostępu: 21.06.2018.

Lorentowicz Jan. „Rapsodia Pomorza”. Tydzień Polski III/25 (1922b): 12-13. https://academica.edu.pl/reading/readSingle?page=12\&uid=56633844, data dostępu: 21.06.2018.

Lorentowicz Jan. „Rapsodia Pomorza”. Tydzień Polski III/26 (1922c): 11-12. https://academica.edu.pl/reading/readSingle?page $=11 \&$ uid $=56633845$; data dostępu: 21.06 .2018 .

Łoch Eugenia. Szkice o twórczości literackiej Stefana Żeromskiego. Lublin 2008.

Markiewicz Henryk, W kręgu Żeromskiego. Rozprawy i szkice historycznoliterackie, Warszawa 1977.

Miller Nepomucen Jan. „S. Żeromski: 'Wiatr od morza’”. Ponowa 5 (1922): 444-445. https:// jbc.bj.uj.edu.pl/dlibra/publication/272484/edition/260580/content?ref=desc, data dostępu: 22.06.2018.

Parandowski Jan. „Pod wrażeniem “Wiatru od morza”. Kurier Poznański 165 (1922). https:// academica.edu.pl/reading/readSingle?page=2\&uid=17771454, data dostępu: 22.06.2018.

Paszek Jerzy. Żeromski. Wrocław 2001.

Pękala Bolesław. Żeromskiego Polska w dniach wolności (czyli o utworach z lat 1918-1925). Bydgoszcz 1982. 
Piwiński Leon. „St. Żeromski: ‘Wiatr od morza”. Przeglad Warszawski III (1922): 102-106. https://academica.edu.pl/reading/readSingle?page=105\&uid=53850802, data dostępu: 22.06.2018.

Podgórscy Barbara i Adam. Wielka księga demonów polskich. Leksykon i antologia demonologii ludowej. Katowice 2005.

Rettinger Mieczysław. „Na wachlarzu z legendy i aktualności”. Kurier Lwowski 122 (1922). https://jbc.bj.uj.edu.pl/dlibra/publication/143242/edition/135115/content?ref=desc, data dostępu: 21.06.2018.

Rzymowski Wincenty. „Z mojego świata”. Świat. Pismo tygodniowe ilustrowane 24 (1922)., https://academica.edu.pl/reading/readSingle?page=16\&uid=10532074, data dostępu: 22.06.2018.

Tomicka Jadwiga. „Wiekuiste dążenie naprzód, naprzód”. Gazeta Lwowska 108 (1922a). https:// jbc.bj.uj.edu.pl/dlibra/publication/43459/edition/37907/content?ref=desc; data dostępu: 25.05.2018;

Tomicka Jadwiga. „Wiekuiste dążenie naprzód, naprzód”. „Gazeta Lwowska” 113 (1922b). https://jbc.bj.uj.edu.pl/dlibra/publication/43474/edition/37920/content?ref=desc, data dostępu: 25.06.2018.

Tyc Teodor. „Epopeja Pomorza”. Strażnica Zachodnia 3 (1922): 88-93. http://www.wbc.poznan. $\mathrm{pl} / \mathrm{dlibra} /$ applet?mimetype $=$ image $\% 2 \mathrm{Fx}$. djvu\&sec $=$ false\&handler $=$ djvu_html5\&content_url=\%2FContent\%2F316255\%2Findex.djvu\&p=90, data dostępu: 21.06.2018.

Адријана Погода-Колођејак

„СНАГА НАРОДА“ ВЕТРА С МОРА СТЕФАНА ЖЕРОМСКОГ. РЕЦЕПЦИЈА ДЕЛА 1922. ГОДИНЕ

\section{Резиме}

Стафан Жеромски је био велики ауторитет пољске интелигенције. У његовим књигама, које су настајале у годинама освајања, приметна је огромна вера у чињеницу да оне за циљ имају подстицање моралне обнове народа кроз неговање патриотских осећања. У Вейру с мора писац дише „снагом народа““ која је по добијању независности била тако потребна, али не политичким елитама већ пре свега обичном, просечном грађанину који је без свести о својој историји сада морао одговорити новом изазову какав је била препорођена Пољска. Жеромски се није плашио великих речи - оне су у том тренутку биле преко потребне како би се градила, васпитавала и развијала „снага народа“" међу Пољацима. Нема сумње да Вет̄ар с мора у потпуности одражава снагу пољског народа.

Кључне речи: Вет̄ар с мора, Жеромски, „снага народа“, препорођена Пољска. 